\title{
Neglected futures. Considering overlooked poverty in Europe
}

\author{
Helmut P. Gaisbauer • Clemens Sedmak
}

Received: 2 October 2014 / Accepted: 28 November 2014 / Published online: 6 December 2014

(C) The Author(s) 2014. This article is published with open access at Springerlink.com

\begin{abstract}
With poverty reduction being one of the five targets of the EU 2020 process, poverty is currently high on the agenda for the European Union and the 27 Member States. The applied methodology of measuring poverty and social exclusion (EU-SILC) calls for critical reflection, because it systematically overlooks absolute or extreme forms of poverty. Thus, the most vulnerable remain invisible. This fact poses a major challenge for future planning and the future of social policies. This article proposes an understanding of poverty as restricted access to relevant futures: a deprivation of access to possibilities and chances. Following this, we argue that "invisible" persons living in conditions of severe poverty are forced into horizons of damaged futures. Furthermore, a failure to "see" these forms of poverty has an impact on the already limited future prospects of these groups on yet another level. The most vulnerable, such as homeless children, undocumented refugees and asylum seekers, migrant beggars and other homeless people, are excluded from both analysis and social policies. This can be regarded as a second-order methodological neglect of relevant futures. Overcoming such second-order neglect is a necessary and first step towards establishing choices about relevant futures for these persons. There is a moral as well as an epistemic responsibility vis-à-vis those "invisible" groups. This is the basis for alleviating conditions of access to relevant futures. The article concludes
\end{abstract}

This article is part of the Topical Collection on The Future of Europe, guest-edited by Markus Pausch.

H. P. Gaisbauer $(\bowtie)$

Centre for Ethics and Poverty Research, University of Salzburg,

Moenchsberg 2a, 5020 Salzburg, Austria

e-mail: helmut.gaisbauer@sbg.ac.at

C. Sedmak

King's College London and Centre for Ethics and Poverty Research, University of Salzburg, Moenchsberg 2a, 5020 Salzburg, Austria

e-mail: clemens.sedmak@sbg.ac.at with a plea for a "visibilization" of non-targeted and unperceived poor persons living in extreme poverty in Europe.

Keywords Absolute poverty $\cdot$ Relative poverty $\cdot$ Social exclusion $\cdot$ Capabilities $\cdot$ EU-SILC $\cdot$ EU 2020 targets

There are some who are in darkness

And the others are in light

And you see the ones in brightness

Those in darkness drop from sight

Bertolt Brecht, The Threepenny Opera

\section{Introduction}

In recent years, poverty has been high on the agenda of the European Union and the 27 Member States. They have engaged in considerable activities to tackle poverty and social exclusion in Europe. The Member States agreed upon a broad range of sophisticated methodologies to measure poverty and exclusion. At the heart of these methodologies is the EU-SILC approach, which provides the most relevant and "visible" data on income and living conditions across Europe including those of millions of households in (income) poverty. A sign of the prominent place of the poverty agenda is the fact that the year 2010 was declared the "European Year Against Poverty and Social Exclusion", a year dedicated to programmes and events aiming to raise academic, political and public awareness regarding poverty and to combat social exclusion more forcefully. Furthermore, one of the five high-profile headline goals of the EU 2020 process was dedicated to the containment of poverty and social exclusion, including explicit quantitative targets. It goes without saying that these efforts and 
intentions are commendable, and in the interest of future social cohesion in Europe.

Some important details of this programmatic process, however, call for critical reflection. The aforementioned methodology, for example, raises serious concerns regarding its validity in the scholarly literature. In line with such criticisms, this article is concerned with the fate of people suffering from poverty that remains largely unmonitored. Absolute, severe or extreme forms of poverty in the middle of Europe are systematically overlooked, and mostly uncaptured by the "poverty radars" measuring poverty in Europe. This is not a minor flaw in political perception created by statistical means, but a major challenge for future planning and the future of social policies.

Our main argument takes as its point of departure an understanding of poverty as restricted access to relevant futures: a deprivation of access to possibilities and chances necessary for the cultivation and realization of human potential. Following this, we argue that "invisible" persons living in conditions of severe poverty are forced into horizons of damaged futures, which will also be the basis for the damaged lives of their children. A failure to "see" these forms of poverty has an impact on the already limited future prospects of these groups on yet another level: processes of social exclusion on the first level of the experience of social exclusion are reiterated on a second level of analysis. In other words: the most vulnerable are excluded from analysis and social policies. This can be regarded as a second-order methodological neglect of relevant futures.

In the first section, we elaborate the argument that poverty can be understood in terms of neglected futures. According to a widely shared concept initially proposed by Amartya Sen, poverty can be conceptualized as a deprivation of capabilities. The term "deprivation" indicates a culpable omission, or even an explicit act robbing someone of the possibility of being someone or doing something. There is a moment of "agency" involved in this analysis. Deprivations of capabilities lead to a limitation of "freedoms to choose", and hence to limitations on the freedoms to plan a life or to build a life in a step-by-step manner. Poor people cannot develop what John Rawls called a "life plan", an architecture of goals and strategies to reach those goals in order to realize their potential. Poverty kills futures. In her well known diary of her life in a favela in São Paulo in the 1950s, Carolina Maria de Jesus talks about the loss of peace of mind resulting from the uncontrollable risks and uncertainties about the future. This is a burden with regard to the "big future" as well as for the "little future" of the day ahead: "In the morning I'm always nervous. I'm afraid of not getting money to buy food to eat" [1]. Poverty kills futures (of adults) and "future futures" (of children). We can read in the diary that there is no future for a child living in severe poverty in a favela: "A child died here in the favela. He was 2 months old. If he had lived he would have gone hungry" [1]. Carolina Maria de Jesus was lucky in the sense that her diary was published and she could move out of the favela. But again, her future was damaged. Robert Levine observed: "By the time she was liberated from the favela by a stroke of fate, it was too late. She was exhausted, too beaten down to learn middle-class manners, to censor her thoughts, to remove the layers of suffering from her psyche" [2]. For a person living in conditions of poverty, a number of relevant future scenarios have been rendered impossible. "Relevant" futures are personally desirable scenarios that can be justified on the grounds of human rights. Poverty limits both conceptions of and access to relevant futures.

In the second section, we develop the idea that under certain circumstances people are confronted with a secondorder neglect. This is the case when well-established academic and political ways of dealing with poverty and poverty alleviation exclude affected groups from their approaches. This epistemic negligence can be described as a drama of neglected futures of a second order. Second-order neglects, we hold, reiterate first-order neglects; they fail to conceptualize firstorder deprivations. The most serious instance of a secondorder neglect of relevant futures is the ignorance of invisible groups. We argue that this is the case in the academic and political discourse with regard to extreme forms of poverty in Europe.

In section three, we demonstrate that such neglect can be identified for the European Union and its Member States. It can be shown that the methodology applied in the EU-SILC panel statistics excludes certain groups of people in absolute poverty, thus denying them proper recognition. This has, of course, implications for action plans against poverty on the first level of poverty alleviation efforts. Overcoming the second-order neglect of relevant futures of these groups is a necessary and first step towards establishing choices about relevant futures for these persons. There is a moral as well as an epistemic responsibility vis-à-vis those "invisible" groups (section 4). This is the basis for alleviated conditions of access to relevant futures. The article concludes with a plea for a "visibilization" of non-targeted and unperceived poor persons living in extreme poverty in Europe.

\section{Poverty as a deprivation of relevant futures}

According to a widely established concept, poverty can be understood as a deprivation of capabilities [3]. Capabilities are real freedoms of being and doing; poverty deprives the person of understanding and realizing her potential, from grasping potentials and possibilities. The idea behind this approach is an Aristotelian understanding of the human person, and can be reconstructed in the following terms: the human person lives within a horizon of possible transformations of the current situation. There are potentials within the person ("potentiae") and "possibilities in the world" ("possibilitates"). These two types of the non-actual have to correspond (X has the potential 
to learn about basic health care, and there is the possibility to act on that learning in a basic health unit). Aristotle, who was interested in conceptualizing motion in the empirical world, describes change in terms of that dynamics of transforming possibilities into actual states of affairs. Change is always about a situation A that is transformed into a situation B. A process of change transforms a current situation $\mathrm{A}$ into a future situation B. In this reading, change involves three types of aspects: a) aspects that begin to exist (and are "future aspects" given the current situation A), b) aspects that cease to exist (and are "future non-aspects" given the current situation $\mathrm{A}$ ), and c) aspects that are constants throughout the process (thus connecting the current situation A with the future situation $\mathrm{B}$ ). The present situation can be analysed against the background of a horizon of possibilities, of future developments of this situation.

The transformation from potential to real happens according to an Aristotelian analysis via movement [4]. Motion is the fulfilment of what exists potentially, insofar as it exists potentially [5]. So, there is a potential for future development put in place. Change (motion) is a fulfilment of a particular potentiality. Motion is brought about by a particular already-existing force, by something that has the power of causing motion. "A thing is capable of causing motion because it can do this, it is a mover because it actually does it" [5]. In other words, motion presupposes something that already exists - things that are capable of that motion [6] and resources that realize the potential. "Incapacity is deprivation of a capacity" [7]. There are two types of incapacity: lack of a particular disposition by its nature (for example: a refrigerator cannot see) and lack of a natural disposition (a blind person cannot see).

This is precisely the point where an understanding of poverty as deprivation of capabilities comes in: a person is deprived of a capability in the sense that the person could own this capability, since the lack of the capability is not the lack of a particular disposition by nature. The term "deprivation" indicates a culpable omission, or even an act robbing someone of the possibility of being someone or doing something. A human person is an entity capable of many motions, e.g., the motion of appropriating literacy and realizing the potential to read and write. The motion to bring about literacy is based on something real, it requires existing resources. These resources (teacher, school, teaching material) need to be in place, as well as the readiness on the side of the person to appropriate the new capability (being able to read and write). This readiness is a matter of having an understanding of oneself as a being capable of obtaining a new skill. A person with low selfesteem, a person who has been told that she is incapable of learning anything, will not have the disposition to appropriate certain capabilities. In this sense, too, poverty is a deprivation of capabilities: poverty deprives persons of possibilities (resources, structures) to realize a particular potential; it deprives poor people of the understanding of their own potential; and, very often, it deprives poor people (because of malnourishment, for instance) of potential.

A deprivation of capabilities leads to a limitation of "freedoms to choose" [8]. The horizon of possible future situations is restricted just as much as the set of possibilities to shape the world on the basis of choices. Again, in an Aristotelian reading so fundamental for the capabilities approach towards poverty, human beings are in a privileged position to shape the world by initiating actions - the origin of action in its efficient cause is choice [9]. Human beings are capable of making choices, based on desires and reasoning. It is precisely this freedom to choose that is limited for people living in poverty. If options and chances are confronted with obstacles and agency is limited, the future is directly put into question; if the development and cultivation of capabilities is restricted, the future is impaired.

Thus, poverty can be understood in terms of disabled or neglected futures. For a person in poverty, a number of relevant future scenarios have been rendered impossible, a set of relevant choices has to be neglected. A poor person can be deprived of a future life as a well-nourished, literate, decently employed person. Poverty limits both conceptions of and access to relevant futures. Relevant futures are humanrights-based conceptions of human transformation. To recognize different forms of poverty, such as absolute poverty, relative poverty or social exclusion, as a limitation to and a neglect of the future is vital for academic and political approaches to poverty.

However, what if established academic and political ways of dealing with poverty and poverty alleviation exclude certain affected groups from their approaches? What if these approaches do not help to make people affected by poverty seen? Such a constellation has to be understood as neglected futures of a second order. In other words, second-order neglects reiterate first-order neglects, i.e., they fail to conceptualize first-order neglects. This is a social pathology according to Axel Honneth. A social pathology deprives people of the possibility to have a good life and of the possibility to conceptualize this deprivation. Social pathologies operate, according to Christoph Zurn's reconstruction of Honneth's approach, "by means of second-order disorders, that is, by means of constitutive disconnects between first-order contents and second-order reflexive comprehension of those contents, where those disconnects are pervasive and socially caused" [10]. ${ }^{1}$ Social pathologies manifest an incongruity between levels of experience and levels of reflexivity.

The most serious instance of a second-order neglect of relevant futures is the ignorance of invisible groups. This is happening in the academic and political discourse with regard

\footnotetext{
${ }^{1}$ A. Honneth in his rejoinder in the same volume accepts this analysis as exceptionally fruitful [11]. A more basic reconstruction of Honneth's concept of social pathologies is provided by Jean-Philippe Deranty [12].
} 
to extreme forms of poverty in Europe. It can be demonstrated - see section 3 - that such neglect can be identified for the European Union and its Member States. The fact that it is precisely those affected by extreme poverty that are in this way neglected calls for action on a first-order and on a secondorder level. Overcoming the second-order neglect of the relevant futures of these groups is a necessary and first step towards establishing choices about relevant futures for these persons. In order to do that, poverty alleviation discourses have to "see" these "invisible" groups and have to adapt their analytical tools accordingly. Let us take a look at these two steps separately.

A second-order neglect of relevant futures: invisible groups

The first step in remedying a second-order neglect of relevant futures is the recognition of invisibility. William Vollman, in his well-known account of forms of poverty worldwide, has described "invisibility" as a key feature of poverty [13]. In many instances, public spaces are denied to the poor (street children, beggars, prostitutes, homeless people); they are made invisible. This is a strategy of "spatial invisibility". The German journalist Günter Wallraff found out for himself in an experiment what it was like to be homeless, live on the streets and sometimes even be "locked up" in a storage container (at times without windows) [14]. The "shelter" becomes a strategy for spatial invisibility. Avishai Margalit, a philosopher from Israel, has described a kind of "blindness" that makes people treat others as if they were objects. He uses the term "blindness to the human aspect" to characterize the inability to see the humanness of a person [15]. Margalit points out that this type of blindness means people look through others or ignore them as though they were not there, and is a key element of anti-colonial literature [15]. In Europe, blindness to the human aspect is an experience recounted by people struggling with poverty and low-income jobs. We give two examples here. The French socio-anthropologist Anna Sam describes how in working as cashier for several years in a supermarket, she was looked at and treated more as an item off the shelf than a living being [16]. Customers were oblivious to the fact that a human individual was operating the tilloften ignoring her completely, without so much as a look or a word. Florence Aubenas, who worked undercover as a lowpaid cleaner for 12 months to find out what it is like to try and make a living, was told in an induction course that she should not expect anyone to pass the time of day with her as a cleaner: this was something she would have to get used to [17]. This is "recognition invisibility": people are present but are treated as if they were objects. Axel Honneth has identified the experience of "seeing through or past" a person as a social pathology [18]. It is a way of denying recognition. There are different ways of ignoring a person, e.g., acting as if she were not present; acting as if she were an object; or acting as if she were not a full person. There is a link between invisibility due to denied recognition and institutional practices that create physical invisibility. The fact that industrialized countries discuss a prohibition for public begging shows this link between an absence of public policies and the attempt to create physical invisibility. $^{2}$

This link between institutional practices and invisibility can also happen on the level of institutional perception. What happens if people affected by poverty are "overlooked" by welfare policies? To put it differently: those people affected by poverty are "visible" if they are institutionally defined and recognized as "poor" - a phenomenon Georg Simmel identified a hundred years ago [21]. A reverse application of this insight to those that are not in the same way "defined" as affected by poverty, implies that they are ultimately and in this sense "invisible" and are therefore not regarded as poor people in need of aid. Institutional "visibility" is the result of basic socio-political decisions. Only those that are considered by the social statistical data are potential beneficiaries of targeted measures of poverty policies. Admittedly, this does not apply to most "universal" welfare services granted to all people on record in the welfare system under consideration of their exact welfare position. But there are "non-recorded" people in dire need. They remain in the darkness, where they drop out of sight. $^{3}$

Heuristic invisibility, that is, the neglect of an official social statistical existence, can be described as neglected futures of a second order, as it affects the bases for decisions over governmental measures for poverty reduction in relation to the affected groups. There are many examples of such heuristic neglect of a second order that do not originate in the field of poverty research; often, however, certain overlaps are obvious: the descendants of African slaves in the United States were not considered to be human beings in the sense that a [white] citizen with full civil rights was. In the country where the Declaration of Independence begins its preamble with the famous passage "We hold these truths to be self-evident, that all men are created equal, that they are endowed by their Creator with certain unalienable Rights, that among these are Life, Liberty and the pursuit of Happiness", the long struggle of African Americans demonstrates how more than 100 years of slavery and more than 200 years of an apartheid regime could be defended and justified even before the $\mathrm{Su}$ preme Court. A similar relation can be identified in the cases of "invisible" housekeepers and caretakers from regions like Central and Eastern Europe or Mexico. These people provide

\footnotetext{
${ }^{2}$ See, for example, a European debate analysed by Joe Doherty et al. [19] and a discussion in Arizona, critically assessed by Julia Koestner [20].

${ }^{3}$ To put it another way (that refers to the structure of a social pathology): they remain in hell. Barbara Müller has pointed out that there is a rich tradition in monastic wisdom talking about hell as a place of darkness ("skotus") - a darkness that precludes the possibility of seeing other persons and seeing the glory of God [22].
} 
extraordinary services in many households of Western Europe or North America, but all too often they become invisible in different ways: they are not considered by social and employment laws or social statistics; even in biographies, they are rarely mentioned.

Such neglected futures of a second order are reflected in the political efforts of the European Union in the area of poverty in the ways these efforts are defined among the EU 2020 goals and, accordingly, in the established political process. There is a dimension of institutional blindness that needs to be considered carefully. People living in extreme poverty, such as homeless children in Eastern Europe, undocumented refugees in Member States of the European Union, homeless people and migrant beggars in European cities, are institutionally invisible. They are not included in the future projections of Europe 2020. Because of this flaw in the methodology and the resulting perception, they are not targeted and thus deprived of relevant futures. A first step to overcoming the first- and second-order neglect of relevant futures is the "visibilization" of non-targeted and unperceived poor living in extreme poverty in Europe. This requires a change in the methodology too.

Neglected relevant futures in Europe: the case of absolute poverty

The second step in fighting second-order neglect of relevant futures, and thus in fighting the social pathology of disconnecting the experience of people from the available tools for analysis, is the reconsideration of the methodology. The "invisibility" of certain groups can be linked to the methodology for approaching poverty in a European context.

Since Peter Townsend's ground-breaking research on relative poverty [23], there has been a latent assumption that "absolute poverty" is a matter for developing countries and the so-called "Third World", whereas industrialized contexts have less severe, less extreme forms of poverty, namely forms of social exclusion considered as relative poverty. Coined by the former president of the World Bank, Robert S. McNamara, in 1973, "absolute poverty" means "a condition of life so degraded by disease, illiteracy, malnutrition, and squalor as to deny its victims basic human rights" [24]. What people affected by such forms of (absolute) poverty lack can be expressed on the basis of the inalienable human rights as follows: absolute poverty is characterized by a lack of rights to nutrition, clean drinking water and safe housing. Understood in this way, absolute poverty indicates a lack of essential basic goods. It is obvious that absolute poverty can be directly translated as a form of neglected futures that must also be considered absolute. Absolute poverty is discussed on a global scale. If global poverty is to be reduced, the involved actors think of absolute poverty. In the Millennium Development Goals (MDGs), the United Nations, the World Bank and other international organizations have set the goal of reducing the number of people living under conditions of absolute or extreme poverty by half from 1990 to 2015 . In order to measure such enormities, such life-threatening afflictions, the following method was defined: people are considered to be absolutely or extremely poor, if they have to live on less than US \$1.25 per day. This method of measuring absolute poverty has drawn a lot of criticism [25]. While these forms of poverty reduction through international programmes tend to result in apparent victories, which seem to be backed up by the collected data, the reality is that the poorest of the poor do often not profit from the implemented measures at all; these programmes, once again, do not improve the situation of those affected by extreme poverty [26]. Possible reasons for this may be costs, careers, or wrong measures taken [11]. This indicates a situation of neglected futures on a higher level, a neglect of a second order on a global scale - but outside Europe.

In accordance with their self-understanding as inclusive welfare states, European countries have developed a more sophisticated method for measuring poverty. The concept of absolute poverty has been reshaped for the developed world, accordingly. Depending on the respective officially recognized method of measurement or social statistics, people in Europe are hence considered to be affected by relative poverty and/or social exclusion if they earn so little that (1) their income is below the at-risk-of-poverty threshold, (2) if they are long-term unemployed against their will, or (3) if they have so little money at their disposal that they are unable to cover the basic needs of the social living standard - e. g., four or more out of nine basic needs according to the EU 2020 standard method (considerable material deprivation). ${ }^{4}$ The atrisk-of-poverty threshold is set at $60 \%$ of the median equivalized disposable income; those earning less than $60 \%$ of this income average are considered to be at risk of poverty. In 2012, this threshold was set at about $€ 1090$ per month in Austria, at about $€ 980$ in Germany, at about $€ 350$ in Slovakia, at about $€ 143$ in Bulgaria, and finally, at only about $€ 105$ in Romania. ${ }^{5}$ The method that is used for the EU 2020 strategy measures poverty and social exclusion by the indicators of low income, low work intensity and/or material deprivation

\footnotetext{
${ }^{4}$ Indicators for not covering these basic needs may be measured by (1) the inability to pay off debts, (2) to cover unexpected costs of up to $€ 650$ per year, (3) to afford an annual holiday (1 week for each member of the household), (4) to keep one's accommodation warm, (5) to regularly include meat, fish or comparable vegetarian food in their diet, or (6) to afford a car, (7) a television set, (8) a washing machine, or (9) a (mobile) phone.

${ }^{5}$ It must be noted that the income of those whose income is below this threshold is usually considerably below it. In Austria, the average income of people at risk of poverty, measured by the so-called poverty gap, was $€ 219$ below the amount set for the threshold in 2012; following these statistics, this means that half of the people at risk of poverty had a regular income of less than $€ 870$ per month. In addition to that, the calculations of these means of measuring income poverty do not consider expenses to pay off debts, for hospital stays, medication or remedies.
} 
according to these thresholds. All indicators are measured on a household level.

As mentioned above, with its EU 2020 strategy, the European Union aims to reduce the number of people affected by poverty and social exclusion in the entire EU area by 20 million people. Generally speaking, not all people affected by poverty who are reached by the welfare state and poverty policy benefit from the applied measures in a way that substantially improves their situation and opens up possibilities and opportunities (poverty is a "wicked problem" that cannot be "solved"). But many cases demonstrate that welfare support does help people at risk of poverty to stay above the (monetary) at-risk-of-poverty threshold. This indication is hard to ignore and points to the (insufficient, but still existing) poverty-avoiding effect of the welfare state's redistribution policy. ${ }^{6}$ This also applies for the EU 2020 process.

The EU 2020 headline target of reducing poverty and social exclusion has been confronted with substantial critique from different sources. Maître, Noland and Whelan raise general questions concerning the validity of the selected methodology [32]. Frazer and Marlier identify similar problems. Interestingly, they raise an argument within the concern of this paper. The authors plead in favour of making the reduction of child poverty a subordinate headline target, as this problem has previously not been sufficiently considered [33]. Finally, Nicaise and Schockaert explicitly approach the question of the extent to which EU-SILC excludes groups of scarcely accessible people affected by poverty; they examine in what ways the items of EU-SILC inadequately document situations of poverty, and furthermore they test an alternative methodology that aims to overcome some of these identified problems. Taking the example of Belgium, they point to the exclusion of an estimated 10,000 travelling circus people and people living on boats or ships ("bargees"), as well as an additional 10,000 Roma, besides other examples. None of these people are considered by the measurements of the EU-SILC. Furthermore, an additional 14,300 people (according to outdated and presumably inadequate estimates) live in unofficial accommodation such as tent camps; for the year 2003, FEANTSA, the European Federation of National Organizations Working with the Homeless, estimated the number of homeless people at 17,000; the authors presume that this number has increased considerably since then [34].

In all of those cases, the exclusion of people affected by absolute poverty is rooted in the methodology. EU-SILC is laid out as a panel survey addressing households; however, many of those affected by extreme poverty do not have permanent accommodation, or do but are unable to use it

\footnotetext{
${ }^{6}$ For a long-term perspective in late post-war Europe, compare Brady [27]. For an analysis of poverty in employment, see Lohmann [28] and Lohmann and Andreß [29]. For recent European data, see Caminada \& Goudswaard [30]; for differences between European welfare systems and the US, see Caminada \& Martin [31].
}

permanently. Their number is considerable: several hundreds of thousands of people spend night after night in the open, in emergency shelters, at other people's homes, or are placed in homes or institutions. Nicaise and Schockaert estimate, for Belgium, that the lack of representation of this group in the EU-SILC's data lowers the ratio of people at risk of poverty by an extent that lies somewhere between 0.6 and $1.7 \%$ [34]. The Belgian example impressively demonstrates that the EU-SILC ignores and excludes some of those people who are most affected by poverty. Such practices distort the assessment of poverty numbers and question the reliability of the applied methodology. The study shows that two independently surveyed groups - homeless people and undocumented refugees - need to be considered as groups most affected by poverty and deprivation [34]. However, the study also shows that the inclusion of these excluded groups requires special methodological attention and sensitivity, on the one hand. On the other, it may reveal especially problematic areas that appear to be relevant for future collections of data, but may also be helpful for the reduction of poverty "on the ground" [34]. The methodological reason for this non-representation cannot be separated from political decisions over certain methodologies of poverty reports. In this case, the invisibility of extremely poor people is caused by methodologies; the responsibility, however, remains at the political and at the scholarly level.

\section{The politics of ignoring or recognizing neglected futures}

The fact that forms of absolute poverty are neglected in Europe deepens the deprivation of relevant futures of the people involved. Academic and social statistical poverty research has a responsibility to be concerned with "relevant futures". This requires an understanding of neglected futures on a meta-level. By understanding neglected futures, academic and political discourse can contribute, e.g., also in cooperation with pressure groups, to resistance to restriction and a fight for the freedoms to choose relevant futures - future lives people have reasons to value. Some of the official reports on poverty and wealth that emerged in Germany during the 1990s serve as an illustrative example, as they are the result of the joint efforts of welfare organizations, communities and devoted academics [35]. These joint efforts are expressions of "concerns about relevant futures".

Poverty alleviation and poverty reduction conducted from academic and political perspectives is therefore at the same time an approach to open life options and to regaining the future: this is as relevant as draining swamps or building dams to the reclamation of land. The aims of these measures are always directed at human beings who are destitute and whose dignity is in danger. In this sense, poverty research and welfare policies work on possibilities for the future on a new level, a future of a second order. "First-order work on the future" is committed to applying results of the analysis of the "second- 
order work on the future". The relationship between first-order futures and second-order futures can be linked to the relationship between tangible and intangible infrastructures. Intangible infrastructures like knowledge and values shape the planning and structure of tangible infrastructures like dams and bridges [36]. Neglecting the intangible infrastructure will inevitably lead to a neglect of tangible structures. Similarly, blind spots in poverty research and/or inactivity of welfare politics need to be regarded as ways of neglecting secondorder futures. In some circumstances, such blind spots as lack of analysis will lead to programmes that do not do justice to the needs of the target groups - that is, if certain groups are targeted at all.

\section{Conclusion}

The most serious instance of a second-order neglect of relevant futures is the ignorance of invisible groups. We have demonstrated such neglect for the anti-poverty policies of the European Union and its Member States: the development and consolidation of reporting on poverty during recent years has favoured the development that the groups most severely affected by poverty have become largely invisible within social statistics. This trend, as well as the failure to provide assistance through poverty policy, becomes evident in the poverty policy programme of the EU 2020 strategy: the strategy's goal is to reduce the number of people affected by poverty and social exclusion by 20 million by 2020, and the Member States' efforts are adjusted to this target. The strategy's subjects are those people whose situation has roughly been identified through a certain methodological approach as relatively poor. However, the statistics do not consider people living under conditions of extreme poverty (i.e., homeless people, undocumented refugees, immigrants escaping from extreme poverty in their home countries, etc.), and accordingly, their destiny is irrelevant for reaching or not reaching the goal of the EU 2020 strategy of a reduction of poverty and social exclusion. The fact that it is precisely those affected by extreme poverty that are in this way neglected poses a serious problem, and calls for action on a first-order and on a second-order level. Overcoming the second-order neglect of relevant futures of these groups is a necessary and first step towards establishing choices about relevant futures for these persons. In order to do that, poverty alleviation discourses have to "see" these "invisible" groups and have to adapt their analytical tools accordingly. This insight into the potentially dramatic consequences of heuristic invisibility of the most vulnerable must be answered by a plea for a widely informed, plural and egalitarian practice of poverty and futures research - a practice that focuses especially on "suppressed" and "under-represented" phenomena from the margins of a society [37]. It also demonstrates the common responsibility of the political and the academic elites to recognize and "see" the most vulnerable and to make them be seen in programmes and theories, in practical tools and future scenarios.

Open Access This article is distributed under the terms of the Creative Commons Attribution License which permits any use, distribution, and reproduction in any medium, provided the original author(s) and the source are credited.

\section{References}

1. de Jesus CM (2003) Child of the Dark. The Diary of Carolina Maria de Jesus. Quarto de Despejo (1960). Penguin, London

2. Levine RM (2003) Afterword. Child of the Dark. The Diary of Carolina Maria de Jesus. Quarto de Despejo (1960). Penguin, London, pp 182-197

3. Sen A (1999) Development as Freedom. Anchor Books, New York

4. Aristotle (2000) Aristotle's Metaphysics Lambda: Symposium Aristotelicum. Clarendon Press; Oxford University Press, Oxford \& New York

5. Aristotle (1983) Physics: book III and IV. Oxford University Press, Oxford

6. Aristotle (1999) Physics: book VIII. Oxford University Press, Oxford

7. Aristotle (1993) Metaphysics. Books [gamma], [delta] and [epsilon]. Clarendon, Oxford

8. Pettit P (2001) Symposium on Amartya Sen's philosophy: 1 Capability and freedom: a defence of Sen. Econ Philos. doi:10. $1017 / \mathrm{S} 0266267101000116$

9. Aristotle (2009) The Nicomacheanethics. Oxford University Press, Oxford

10. Zurn CF (2011) Social Pathologies as Second-Order Disorders. In: Petherbridge D (ed.) Axel Honneth: Critical Essays. With a reply by Axel Honneth, 1st ed. Brill Academic Publishers, Leiden, pp. 345370

11. Honneth A (2011) Rejoinder. In: Petherbridge D (ed) Axel Honneth: Critical Essays. With a Reply by Axel Honneth. Brill, Leiden, pp 391-421

12. Deranty J-P (2009) Beyond Communication. A Critical Study of Axel Honneth's Social Philosophy, 1st ed. Brill Academic Publishers, Leiden

13. Vollman WT (2007) Poor people. Harper Collins, New York

14. Wallraff G (2009) Aus der schönen neuen Welt: Expeditionen ins Landesinnere, 1. Aufl. Kiepenheuer \& Witsch, Köln

15. Margalit A (1996) The Decent Society, 1st edn. Harvard University Press, Cambridge

16. Sam A (2009) Checkout: a life on the tills. Gallic Books, London

17. Aubenas F (2010) Le quai de Ouistreham. Olivier, Paris

18. Honneth A (2001) Invisibility: On the Epistemology of "Recognition.".Proc Aristot Soc Suppl Vol 75:111-116

19. Doherty J, Busch-Geertsema V, Karpuskiene V et al (2008) Homelessness and Exclusion: Regulating public space in European Cities. Surveill Soc 5:290-314

20. Koestner J (2013) Begging the (First Amendment) Question: The Constitutionality of Arizona's Prohibition of Begging in a Public Place. Ariz State Law J 45:1227-1249

21. Simmel G (1906) Zur Soziologie der Armut. Arch Sozialwissenschaft Sozialpolitik 22:1-3

22. Müller B (2000) Der Weg des Weinens: die Tradition des "Penthos" in den Apophthegmata Patrum. Vandenhoeck und Ruprecht, Göttingen 
23. Townsend P (1979) Poverty in the United Kingdom. A Survey of Household Resources and Standards of Living, 1st ed. University of California Press, Berkeley, CA

24. McNamara R (1973) The Nairobi Speech. Address to the Board of Governors

25. Reddy SG, Pogge T (2010) How Not to Count the Poor. In: Anand S, Segal PD, Stiglitz JE (eds) Debates on the measurement of global poverty, 1st edn. Oxford University Press, Oxford, pp 42-85

26. Øyen E (2009) The Paradox of Poverty Research: Why is Extreme Poverty Not in Focus? In: Mack E, Schramm M, Klasen S, Pogge T (eds.) Absolute Poverty and Global justice: Empirical Data, Moral Theories, Initiatives, 1st ed. Ashgate, Farnham \& Burlington, VT, pp. 259-271

27. Brady D (2005) The Welfare State and Relative Poverty in Rich Western Democracies, 1967-1997. Soc Forces 83:1329-1364

28. Lohmann H (2009) Welfare States, Labour Market Institutions and the Working Poor: A Comparative Analysis of 20 European Countries. Eur Sociol Rev 25:489-504

29. Andreß H-J, Lohmann H (2008) The Working Poor in Europe: Employment, Poverty and Globalisation, 1st ed. Edward Elgar, Cheltenham, UK \& Northampton, MA

30. Caminada K, Goudswaard K (2009) Differences in Anti-Poverty Approaches in Europe and The United States: A Cross-Atlantic Descriptive Policy Analysis. Poverty Public Policy. doi:10.2202/ 1944-2858.1023
31. Caminada K, Martin MC (2011) Differences in anti-poverty approaches in Europe and the United States: a cross-Atlantic descriptive policy analysis. Poverty Public Policy. doi:10.2202/1944-2858.1153

32. Maitre B, Nolan B, Whelan CT (2013) A critical evaluation of the EU 2020 poverty and social exclusion target: an analysis of EU-SILC 2009. UCD Geary Institute, Dublin

33. Frazer H, Marlier E (2011) Assessment of Progress Towards the Europe 2020 Social Inclusion Objectives. Main Findings and Suggestions on the Way Forward. EU Network of Independent Experts on Social Exclusion, Brussels

34. Nicaise I, Schockaert I (2014) The hard-to-reach among the poor in Europe: lessons from Eurostat's EU-SILC survey in Belgium. In: Tourangeau R, Edwards B, Johnson TP et al (eds) Hard-to-survey populations. Cambridge University Press, Cambridge, pp 1246-1279

35. Hartmann H (2002) Armuts- und Reichtumsberichterstattung in der Bundesrepublik Deutschland. In: Sell S (ed) Armut als Herausforderung: Bestandsaufnahme und Perspektiven der Armutsforschung und Armutsberichterstattung. Duncker \& Humblot, Berlin, pp 155-167

36. Sedmak C (2013) Intangible Infrastructures and Identity. In: Kapferer E, Koch A, Sedmak C (eds.) Strengthening Intangible Infrastructures. pp. 3-22

37. Sedmak C (2013) "Sollen sie doch Kuchen essen". Wissen von Armut. In: Gaisbauer HP, Kapferer E, Koch A, Sedmak C (eds) Armut und Wissen: Reproduktion und Linderung von Armut in Schule und Wissenschaft. Springer VS, Wiesbaden, pp 177-198 